\title{
KAJIAN POTENSI PENGEMBANGAN EKOWISATA BERBASIS EDUKASI DI KAWASAN WADUK SEI LADI KOTA BATAM
}

\author{
Yoseph Seno Prakoso ${ }^{1,}$ Carissa Dinar Aguspriyanti² \\ ${ }^{1}$ Universitas Internasional Batam, email: yoseph.seno@uib.edu \\ ${ }^{2}$ Universitas Internasional Batam, email: carissa@uib.ac.id
}

\begin{abstract}
In order to increase the tourism potential of Batam City which is still focused on coastal tourism, the development of Waduk Sei Ladi provides an interesting alternative to natural tourist attractions. As a means of providing water resources, the existence of Waduk Sei Ladi is quite significant. The tourism development in this area, hence, should be based on sustainable and eco-friendly development (ecotourism). It is equally important that the local communities are involved in the planning and development process as well as its management so that sustainable development can be achieved. Not to mention that the involvement can be part of the implementation of education-based ecotourism in which the communities are able to gain wider knowledge throughout the process. The key finding of this research is that Waduk Sei Ladi has a great potential to be an education-based ecotourism. This is supported by its diverse existing attractions, positive community perceptions of development in the area, and local government policies that also support the development of Waduk Sei Ladi as an eco-friendly object tourism.
\end{abstract}

Keywords: Education-based Ecotourism, Waduk Sei Ladi

\begin{abstract}
Abstrak
Dalam upaya meningkatkan potensi pariwisata Kota Batam yang masih terfokus pada wisata pantai, pengembangan Waduk Sei Ladi dapat memberikan alternatif destinasi wisata alam yang menarik. Sebagai sarana penyediaan sumber daya air, keberadaan Waduk Sei Ladi cukup signifikan. Oleh karena itu, pengembangan pariwisata di kawasan tersebut harus berasaskan pembangunan berkelanjutan dan berwawasan lingkungan (ekowisata). Hal yang sama pentingnya, yakni keterlibatan masyarakat setempat dalam proses perencanaan dan pengelolaannya sehingga pengembangan yang berkelanjutan dapat terwujud, serta dapat menjadi bagian dari implementasi pengembangan kawasan ekowisata berbasis edukasi, di mana masyarakat dapat memperoleh pengetahuan yang lebih luas dalam prosesnya. Penelitian ini menemukan bahwa kawasan Waduk Sei Ladi memiliki potensi yang baik untuk dikembangkan sebagai kawasan ekowisata berbasis edukasi. Hal ini didukung dengan adanya daya tarik kawasan yang beragam, persepsi masyarakat yang positif terhadap pengembangan di kawasan tersebut, dan kebijakan pemerintah setempat yang juga mendukung pengembangan kawasan Waduk Sei Ladi sebagai objek wisata berwawasan lingkungan.
\end{abstract}

\section{Kata-kunci : Ekowisata Berbasis Edukasi, Waduk Sei Ladi}

\section{Pendahuluan}

Kota Batam, dengan beberapa obyek wisata menariknya, terus melalukan pengembangan dari tahun ke tahun untuk menarik wisatawan lokal maupun dari luar Kota Batam. Pengembangan kepariwisataan sebuah kota harus menyesuaikan preferensi para wisatawan yang menjadi sasaran di samping tetap menjaga kharateristik kota itu sendiri.

Lebih lanjut, Rubenstein (1969) menegaskan bahwa ada hubungan antara proses studi lokasi tapak dengan lingkungannya. Pembangunan yang ideal adalah pembangunan yang memiliki harmonisasi dengan tapak dan lingkungannya. Oleh karena itu, pengembangan wisata yang direncanakan harus berdasarkan potensi yang ada baik di lingkungan internal maupun faktor lingkungan eksternal yang ada.

Sarana obyek wisata alam di Kota Batam masih terfokus pada wisata pantai di pinggir kota. Belum ada alternatif lain yang ditawarkan oleh pemerintah setempat. Walaupun sebenarnya ada beberapa lokasi yang potensial untuk dijadikan sebagai wisata alam, salah satunya Waduk Sei Ladi. Keberadaan Waduk Sei ladi di Kota Batam sebagai sarana penyediaan sumber daya air, cukup signifikan mengingat kenyataan bahwa di 
Pulau Batam tidak tersedia sungai besar yang mengalir sepanjang tahun. Oleh karena itu, pengembangannya harus berasaskan pembangunan berkelanjutan dan berwawasan lingkungan demi menjaga kelestariannya.

Untuk mewujudkan obyek wisata berwawasan lingkungan - atau dikenal dengan istilah ekowisata yang berkelanjutan, keterlibatan masyarakat setempat juga dinilai penting baik dalam perencanaan, pembangunan maupun pengelolaannya. Selain meningkatkan sense of belonging terhadap kawasan, diharapkan keterlibatan masyarakat tersebut dapat secara tidak langsung menjadi media edukasi atau pengembangan Sumber Daya Manusia di Kota Batam.

Oleh karena itu, diperlukan penelitian ini sebagai kajian awal terhadap potensi pengembangan Waduk Sei Ladi untuk melihat kemungkinan terciptanya kawasan ekowisata berbasis edukasi, yang dapat dinikmati oleh masyarakat lokal dan luar serta menjadi nilai tambah Kota Batam di masa yang akan datang.

\section{Tinjauan Pustaka}

\section{Pendekatan Pengembangan Kawasan Tepi Waduk}

Sebagai salah satu elemen fisik kota, kawasan tepi air atau waterfront memiliki potensi menjadi wadah aktivitas masyarakat dengan berbagai macam fungsi di dalamnya. Breen (1994) mengkategorikan waterfront berdasarkan beberapa aspek (Tabel 1). Kawasan tepi waduk memiliki potensi untuk dikembangkan sebagai area waterfront dengan berbagai macam fungsi yang mampu memenuhi kebutuhan aktivitas masyarakat sebagai pengguna. Namun, penting untuk diperhatikan bahwa penataan atau perencanaan kawasan waterfront tidak hanya memandang aspek arsitektural tetapi perlu memperhatikan aspek lain seperti keteknikan, sosial budaya, dan peraturan yang berlaku (Breen et al., 1994).

Aspek arsitektural di sini erat kaitannya dengan pembentukan citra dari kawasan waterfront dan pemenuhan nilai-nilai estetika dari kawasan waterfront. Sedangkan aspek keteknikan menitikberatkan pada perencanaan struktur dan penentuan konstruksi yang dapat mengatasi permasalahan-permasalahan yang ada dalam mewujudkan rancangan waterfront. Untuk aspek sosial budaya, yang perlu diperhatikan adalah bagaimana perencanaan yang dibuat mampu meningkatkan kualitas hidup (quality of life) masyarakat yang tinggal di sekitar kawasan waterfront tersebut. Tidak kalah penting adalah aspek peraturan, di mana pemanfaatan ruang dan pelestarian lingkungan waterfront haruslah sejalan dengan tata aturan yang berlaku.

Untuk meminimalisir dampak yang muncul akibat pengembangan waterfront, diperlukan konsep pengembangan yang efektif dan fungsional, di mana terdapat harmonisasi antara unsur terbangun dengan air dan lingkungan sekitarnya. Salah satu contohnya, disampaikan oleh Prabudiantoro (1997), adalah adanya dominasi pemandangan dan orientasi ke arah perairan.

Tabel.1 Kategori Waterfront Menurut Breen (1994)

\begin{tabular}{|l|l|}
\hline \multicolumn{2}{|c|}{ Tipe-Tipe Waterfront } \\
\hline Berdasarkan pertemuan & Waterfront Tepi Sungai \\
& Waterfront Tepi Laut \\
& Waterfront Tepi Danau \\
\hline Berdasarkan aktivitas & Cultural waterfront \\
& Mewadahi aktivitas budaya dan pendidikan \\
& Environmental waterfront \\
& Mewadahi aktivitas peningkatan kualitas lingkungan yang \\
& mengalami degradasi \\
& Historical waterfront \\
& Terbentuk dari usaha konservasi dan restorasi kawasan atau \\
& bangunan bersejarah di area tepi air \\
& Mixed-use waterfront \\
& Menggabungkan berbagai macam fungsi seperti perdagangan, \\
& perumahan, rekreasi, dan sebagainya \\
& Recreational waterfront \\
& Mewadahi aktivitas rekreasi yang dilengkapi dengan berbagai \\
& fasilitas pendukung seperti area bermain, taman, dan \\
& sebagainya) \\
& Residential waterfront \\
& Berfungsi sebagai perumahan atau permukiman \\
Working waterfront
\end{tabular}




\begin{tabular}{|l|l|}
\hline & $\begin{array}{l}\text { Mewadahi aktivitas yang berhubungan dengan kelautan dan } \\
\text { perikanan seperti penyimpanan dan pengolahan hasil laut }\end{array}$ \\
\hline
\end{tabular}

\section{Ekowisata Berbasis Edukasi}

Peraturan Menteri Dalam Negeri Nomor 33 Tahun 2009 Republik Indonesia tentang Pedoman Pengembangan Ekowisata di Daerah mengamanatkan bahwa prinsip utama dalam mengembangkan kawasan ekowisata adalah konservasi sumber daya alam yang berkontribusi dalam menyumbang manfaat bagi masyarakat lokal dan menjadi penggerak pembangunan ekonomi setempat, bersifat edukatif, mampu memberikan pengalaman menyenangkan kepada pengunjung, dan melibatkan masyarakat lokal dalam proses perencanaan, pemanfaatan, dan pengendalian ekowisata, serta menghormati kearifan lokal (Peraturan Menteri Dalam Negeri, 2009).

Fennell (2003) di dalam bukunya yang berjudul Ecotourism: An Introduction, menambahkan bahwa ekowisata adalah suatu konsep wisata berbasis alam yang berkelanjutan dan menitikberatkan pada pengalaman serta pembelajaran yang berkaitan dengan alam, dikelola dengan sistem tertentu hingga meminimalisir dampak buruk terhadap lingkungan, tidak konsumtif, dan menitikberatkan pada aspek lokalitas (dalam hal kontrol dan manfaat yang diperoleh dari kegiatan usaha). Sejalan dengan pemikiran Fennel, Wood (2002) dalam Arida (2017) juga mendukung ekowisata sebagai kegiatan wisata berbasis alam yang mengikutsertakan kegiatan budaya setempat.

Kebermanfaatan untuk masyarakat lokal penting untuk dihadirkan dalam setiap pengembangan ekowisata. Keuntungan yang diperoleh masyarakat dari ekowisata bisa dari aspek ekonomi dan sosial budaya. Dari segi ekonomi, sektor pariwisata mampu menyediakan peluang pemasukan bagi pemerintah dan masyarakat. Sedangkan dari segi sosial budaya sektor ini dapat menjadi sarana edukasi dan pemberdayaan masyarakat setempat untuk lebih memahami permasalahan di wilayahnya, serta merumuskan solusi yang bijak untuk mengatasi permasalahan tersebut (Phillips \& Pittman, 2014). Keterlibatan masyarakat ini diharapkan dapat mewujudkan sinergi yang baik di antara sektor pariwisata dan masyarakat demi keberlanjutan kawasan wisatanya.

Selain itu, Inskeep (1991) dalam Phillips \& Pittman (2014) menambahkan bahwa ekowisata juga dapat membantu mencapai sasaran konservasi lingkungan jika direncanakan dengan baik. Karena melalui ekowisata, seluruh komponen terkait dan wisatawan yang berkunjung dapat memiliki apresiasi lingkungan yang tinggi.

Dalam merencanakan pengembangan ekowisata, beberapa hal yang perlu diperhatikan antara lain (1) jenis ekowisata; (2) informasi yang meliputi daya tarik dan keunikan dari alam setempat, kondisi lingkungan, sosial-budaya, ekonomi, peruntukan kawasan, sarana dan prasarana, dan sumber pendanaan; (3) potensi pangsa pasar; (4) hambatan; (5) lokasi; (6) luas; dan (7) batas (Peraturan Menteri Dalam Negeri, 2009).

\section{Metode}

Penelitian yang dilakukan merupakan penelitian kuantitatif dan kualitatif dengan metode pendekatan perencanaan yaitu proses menyusun konsepsi dasar suatu rencana desain. Alur proses penelitian dapat dilihat pada Gambar 1.

\section{Metode Pengumpulan dan Pengolahan Data}

Survey lokasi dan wawancara dilakukan untuk memperoleh data primer, sedangkan mempelajari peta lokasi dan pustaka-pustaka terkait dilakukan untuk memperoleh data sekunder. Narasumber wawancara yaitu Badan Usaha Fasilitas dan Lingkungan BP Batam khususnya Manager Air Baku, sebagai perwakilan pihak pemerintah yang dipilih langsung melalui metode purposive sampling karena dengan asumsi narasumber tersebut telah menguasai materi. Selain itu, kuesioner juga disebar kepada masyarakat yang berdomisili di Kota Batam menggunakan metode random sampling dengan jumlah responden 100 orang untuk mendapatkan persepsi masyarakat terhadap potensi pengembangan ekowisata berbasis edukasi di kawasan Waduk Sei Ladi.

Data-data yang terkumpul akan diolah melalui proses identifikasi komponen-komponen utama sesuai pedoman perencanaan yang tertuang pada Peraturan Menteri Dalam Negeri Nomor 33 Tahun 2009 terkait Pedoman Pengembangan Ekowisata di Daerah (Peraturan Menteri Dalam Negeri, 2009). 
Jurnal Arsitektur AIUR - Vol 4 No 1 Mei 2021

e-ISSN 2685-1490; p-ISSN 2615-1472

\section{Metode Analisis Data}

Analisis SWOT dilakukan untuk mengungkap hasil temuan yang menjadi pertimbangan dalam penyusunan konsep pra-desain pengembangan wilayah penelitian. Konsep tersebut divisualisasikan melalui gambar 3D dan rencana tapak (siteplan) yang menggambarkan potensi pengembangan ekowisata di wilayah penelitian.

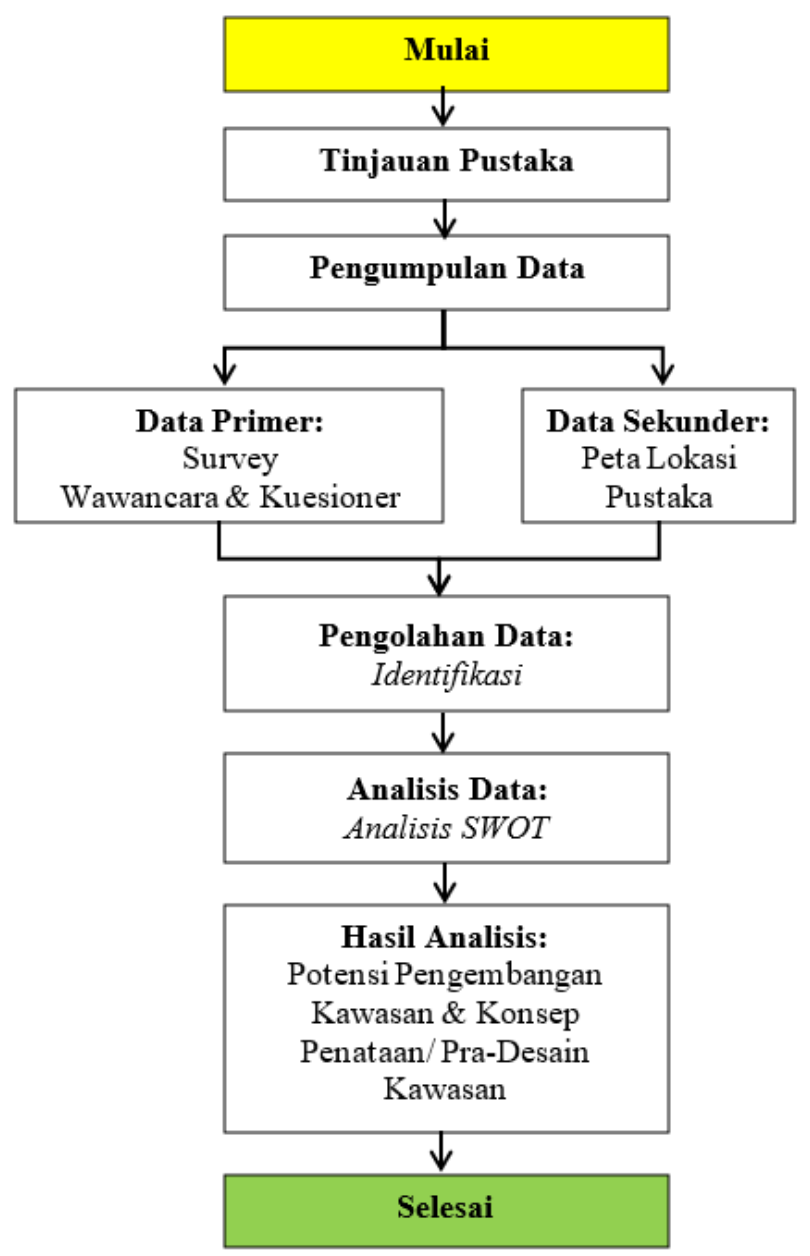

Gambar 1. Diagram Alur Proses Penelitian

\section{Analisis dan Pembahasan}

\section{Identifikasi Kondisi Eksisting dan Analisis SWOT}

\section{a) Kondisi Lingkungan}

Waduk Sei Ladi yang berada di tengah kota ini dikelilingi oleh perumahan dan beberapa institusi pendidikan seperti Universitas Internasional Batam dan SMK Kartini Kota Batam, serta dekat dengan Hotel Crown Vista. Dari peta topografi, diketahui bahwa wilayah penelitian memiliki variasi ketinggian di beberapa titik dengan kemiringan 10-40\%. Kondisi lingkungan kawasan Waduk Sei Ladi terlihat bersih dan asri dengan adanya hutan di sekitar waduk. Hal ini akan dapat mendukung konsep pengembangan wisata alam berwawasan lingkungan atau ekowisata. Keberadaan badan waduk sendiri menawarkan keunikan alam yang menjadi daya tarik tersendiri di kawasan tersebut. 

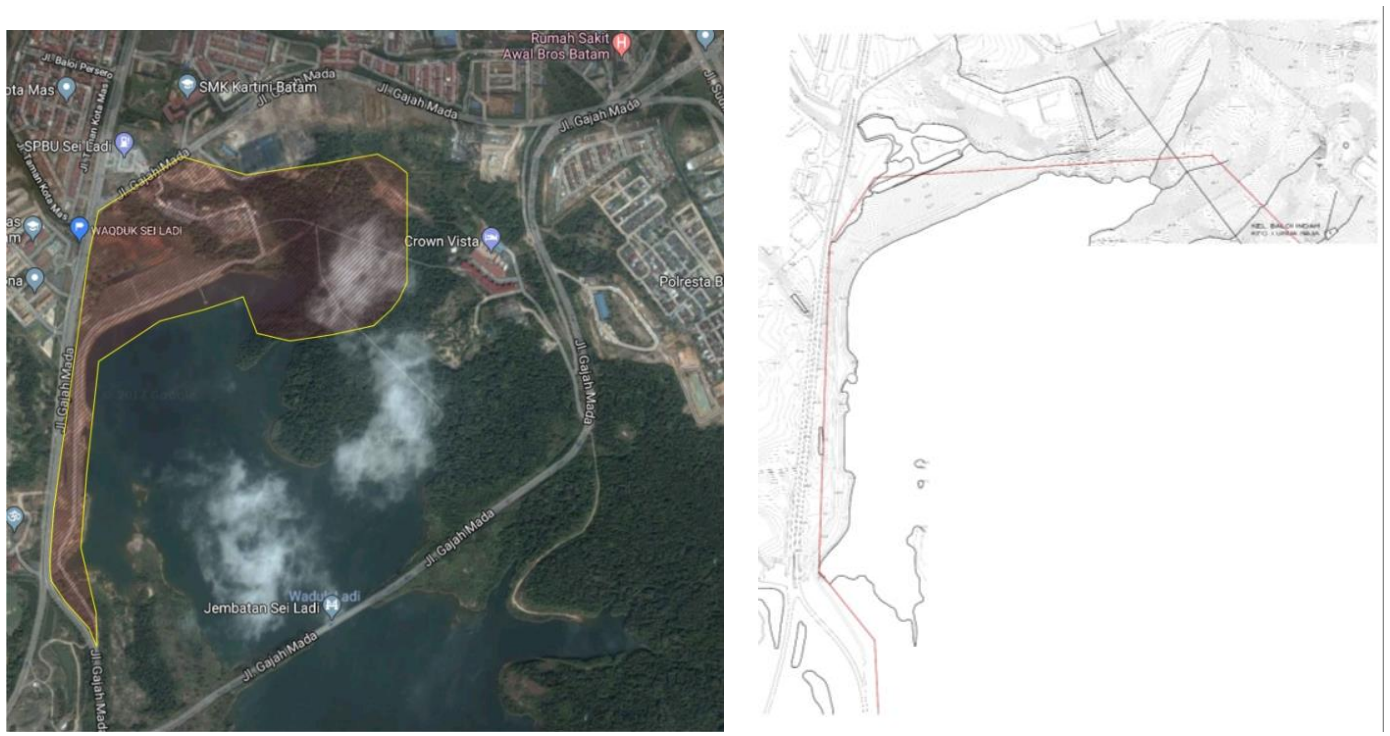

Gambar 2. Peta Lokasi dan Topografi Kawasan Waduk Sei Ladi

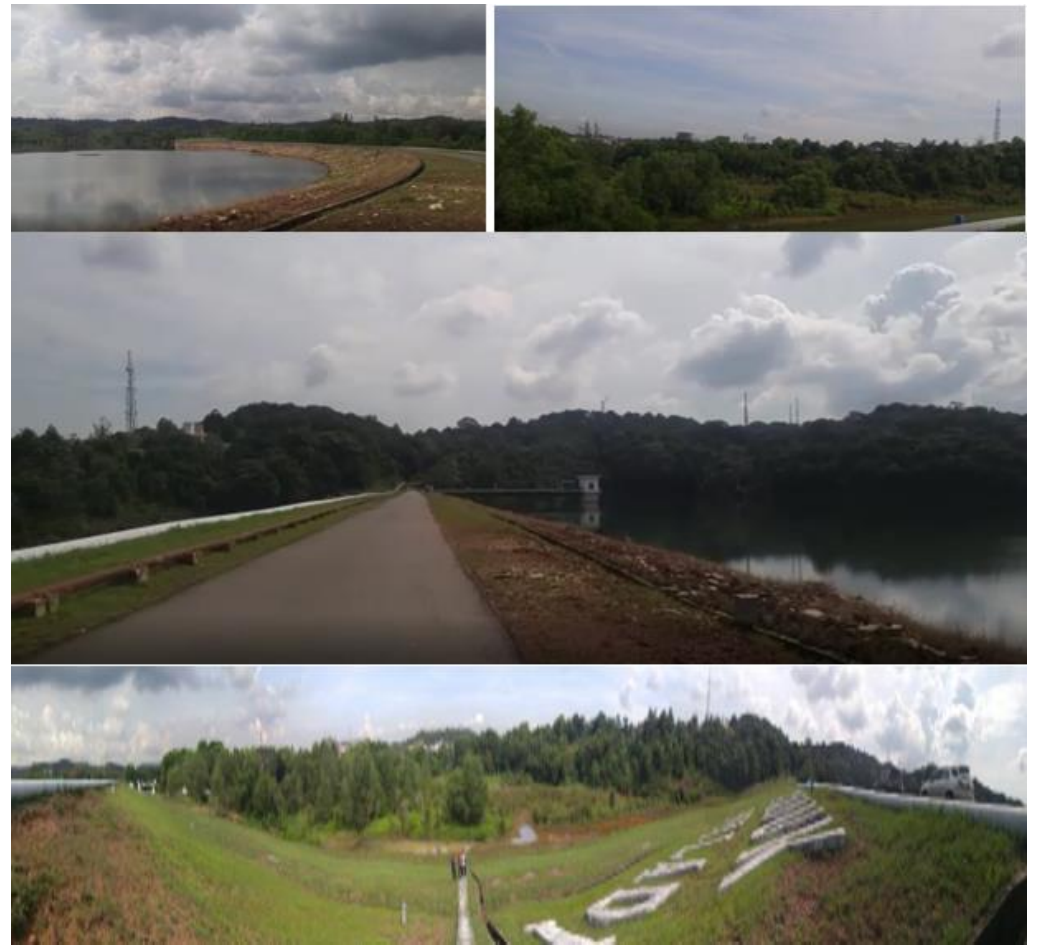

Gambar 3. Kondisi Eksisting Waduk Sei Ladi

b) Kondisi Sosial, Budaya, dan Ekonomi

Penduduk Kota Batam di tahun 2019 berjumlah 1.107.551 jiwa dengan nilai upah minimum sebesar 4.130.279 rupiah dan nilai ini cukup berbeda dengan nilai upah minimum di Kepulaun Riau yang hanya berkisar tiga juta rupiah (Badan Pusat Statistik Kota Batam, 2020b). Wilayah penelitian berbatasan dengan perumahan dan permukiman penduduk, serta fasilitas-fasilitas umum lainnya seperti pendidikan. Oleh karena itu, dapat dikatakan bahwa lokasi kawasan ini cukup strategis untuk dikembangkan sebagai kawasan ekowisata berbasis edukasi. Secara umum, kebudayaan Melayu merupakan akar budaya lokal 
masyarakat Kota Batam, sehingga kearifan lokal ini harus tetap dijaga dalam pengembangan kawasan tersebut.

\section{c) Kondisi Sarana dan Prasarana}

Berdasarkan hasil survey dan wawancara dengan Badan Usaha Fasilitas dan Lingkungan BP Batam sebagai pengelola Waduk Sei Ladi, hanya ada sarana dan prasarana dasar di kawasan waduk tersebut. Sehingga diperlukan pembangunan sarana dan prasarana lain guna menunjang aktivitas kawasan ekowisata nantinya.

\section{d) Peruntukkan Kawasan}

Berdasarkan hasil wawancara dengan Badan Usaha Fasilitas dan Lingkungan BP Batam, kawasan Waduk Sei Ladi memang direncanakan untuk dikembangkan sebagai kawasan wisata tanpa mengurangi fungsi utamanya sebagai objek vital penyedia air di wilayah Kota Batam. Dengan demikian, perlu diperhatikan terkait perlindungan terhadap ekosistem yang sudah ada, khususnya dalam mencegah terjadinya pencemaran. Hal yang perlu dipertimbangkan lainnya adalah, sesuai peraturan peruntukan kawasan, bagian badan waduk tidak diperbolehkan dibangun atau ditanami pohon.

\section{e) Potensi Pangsa Pasar}

Pada tahun 2019, rata-rata jumlah wisatawan mancanegara yang melakukan kunjungan ke Batam tiap bulannya adalah $162.331,5$ orang dan rata-rata jumlah wisatawan lokal sebesar 154.082,25 orang (Badan Pusat Statistik Kota Batam, 2020a). Hal ini menunjukan potensi pangsa pasar yang cukup besar. Ditambah dengan hasil kuesioner persepsi masyarakat yang berdomisili di Kota Batam terhadap pengembangan ekowisata berbasis edukasi di kawasan Waduk Sei Ladi yang menunjukkan bahwa:

- Daya tarik kawasan Waduk Sei Ladi adalah pertama memiliki pemandangan yang indah, lalu disusul dengan dapat menjadi pilihan tempat belajar tentang alam khususnya yang berkaitan dengan air dan hutan, menjadi pilihan tempat bersepeda, lokasi strategis atau mudah diakses, lingkungan asri dan sejuk, dan terakhir, menjadi pilihan tempat rekreasi keluarga.

- Sebanyak $86 \%$ responden berpendapat bahwa dengan daya tarik tersebut, kawasan Waduk Sei Ladi berpotensi untuk dikembangkan menjadi kawasan ekowisata. Namun ada beberapa hal yang perlu ditingkatkan dari kondisi eksisting saat ini seperti keberagaman fasilitas atau kegiatan yang ditawarkan, kualitas sarana dan prasarana, dan perlindungan dari aktivitas yang dapat mencemari lingkungan di kawasan tersebut.

- Dalam pengembangan ekowisata, ada fasilitas atau atraksi yang perlu diprioritaskan antara lain yang pertama taman rusa, kedua teater terbuka, ketiga menara pandang, keempat penyewaan sepeda, lalu disusul dengan fasilitas edukasi lain seperti rainbow/botanical garden, galeri air dan beberapa fasilitas lainnya seperti restoran, tree walk, forest bike trail, dan yang terakhir adalah flying fox.

- Sebanyak $89 \%$ responden berpendapat bahwa pengembangan ekowisata di kawasan Waduk Sei Ladi dapat memberikan manfaat bagi masyarakat dan lingkungan (memberikan alternatif destinasi wisata alam dan budaya di tengah kota, dan membuka lapangan pekerjaan baru).

- Sebanyak $83 \%$ responden berpendapat bahwa keterlibatannya dalam proses perencanaan awal ini dapat memberikan wawasan dan edukasi khususnya terhadap permasalahan dan potensi di kawasan Waduk Sei Ladi serta lingkungan secara umum.

Tabel.2 Analisis SWOT terhadap Pengembangan Ekowisata Berbasis Edukasi di Kawasan Waduk Sei Ladi Kota Batam

\begin{tabular}{|c|c|}
\hline Aspek & Keterangan \\
\hline $\begin{array}{l}\text { Strength } \\
\text { (Kekuatan) }\end{array}$ & $\begin{array}{l}\text { 1. Lokasi strategis di tengah kota sehingga mudah diakses dan dekat dengan } \\
\text { fasilitas umum seperti institusi pendidikan dan hotel. } \\
\text { 2. Memiliki daya tarik kawasan yang beragam, dua di antaranya adalah lingkungan } \\
\text { 3. Memiliki kontur yang bervariasi. } \\
\text { 4. Persepsi masyarakat yang positif terhadap potensi pengembangan di kawasan } \\
\text { tersebut. }\end{array}$ \\
\hline $\begin{array}{l}\text { Weakness } \\
\text { (Kelemahan) }\end{array}$ & $\begin{array}{l}\text { 1. Belum memiliki sarana dan prasarana yang memadai untuk kegiatan ekowisata. } \\
\text { 2. Belum terdapat keberagaman fasilitas atau kegiatan yang ditawarkan. } \\
\text { 3. Belum terdapat sistem pencegahan atau perlindungan dari aktivitas yang } \\
\text { berpotensi mencemari lingkungan. }\end{array}$ \\
\hline $\begin{array}{l}\text { Opportunity } \\
\text { (Peluang) }\end{array}$ & $\begin{array}{l}\text { 1. Pengembangan jenis ekowisata hutan dan waduk. } \\
\text { 2. Pengembangan sarana dan prasarana guna menunjang aktivitas ekowisata } \\
\text { 3. Perbasis edukasi. }\end{array}$ \\
\hline
\end{tabular}




\begin{tabular}{|l|l|l|}
\hline & \multicolumn{2}{|c|}{$\begin{array}{l}\text { sehingga dapat diwujudkan melalui beberapa tahap atau fase konstruksi. } \\
\text { Penambahan sistem pencegahan atau perlindungan dari aktivitas yang } \\
\text { berpotensi mencemari lingkungan. }\end{array}$} \\
\hline $\begin{array}{l}\text { Threat } \\
\text { (Ancaman) }\end{array}$ & 1. Adanya aktivitas yang berpotensi mencemari waduk dan lingkungan. \\
\hline
\end{tabular}

\section{Konsep Penataan/ Pra-Desain Kawasan}

Berdasarkan hasil analisis, ditemukan bahwa kawasan Waduk Sei Ladi berpotensi untuk dikembangkan sebagai kawasan ekowisata berbasis edukasi. Ada beberapa fasilitas yang ditambahkan dari hasil kuesioner atau analisis sebelumnya yakni area bermain, photobooth, gazebo, camping ground, dan handcraft gallery. Pertimbangannya adalah area bermain ditujukan kepada pengguna anak-anak agar kawasan wisata ini dapat lebih menjadi kawasan wisata keluarga; photobooth sebagai fasilitas pendukung jika pengunjung ingin mengabadikan momen di kawasan wisata ini; gazebo dapat disebar di beberapa titik sebagai tempat peristirahatan, mengingat kawasan wisata ini cukup luas; camping ground untuk memfasilitasi pengunjung yang ingin belajar lebih jauh tentang alam yang ada di kawasan wisata ini; dan handcraft gallery lebih ditujukan untuk memberdayakan pengrajin-pengrajin lokal bernuansa Melayu sehingga pengembangan kawasan ekowisata ini dapat turut membantu meningkatkan perekonomian kota serta melestarikan kearifan lokal. Fasilitas-fasilitas yang direncanakan secara keseluruhan dapat diwujudkan melalui empat fase konstruksi, di mana fase tersebut mempertimbangkan hasil kuesioner. Selain itu, berdasarkan lokasi, keseluruhan kawasan dibagi menjadi tiga zona.

Adapun visualisasi konsep pra-desain kawasan tersebut dengan mempertimbangkan hasil analisis, sebagai berikut:

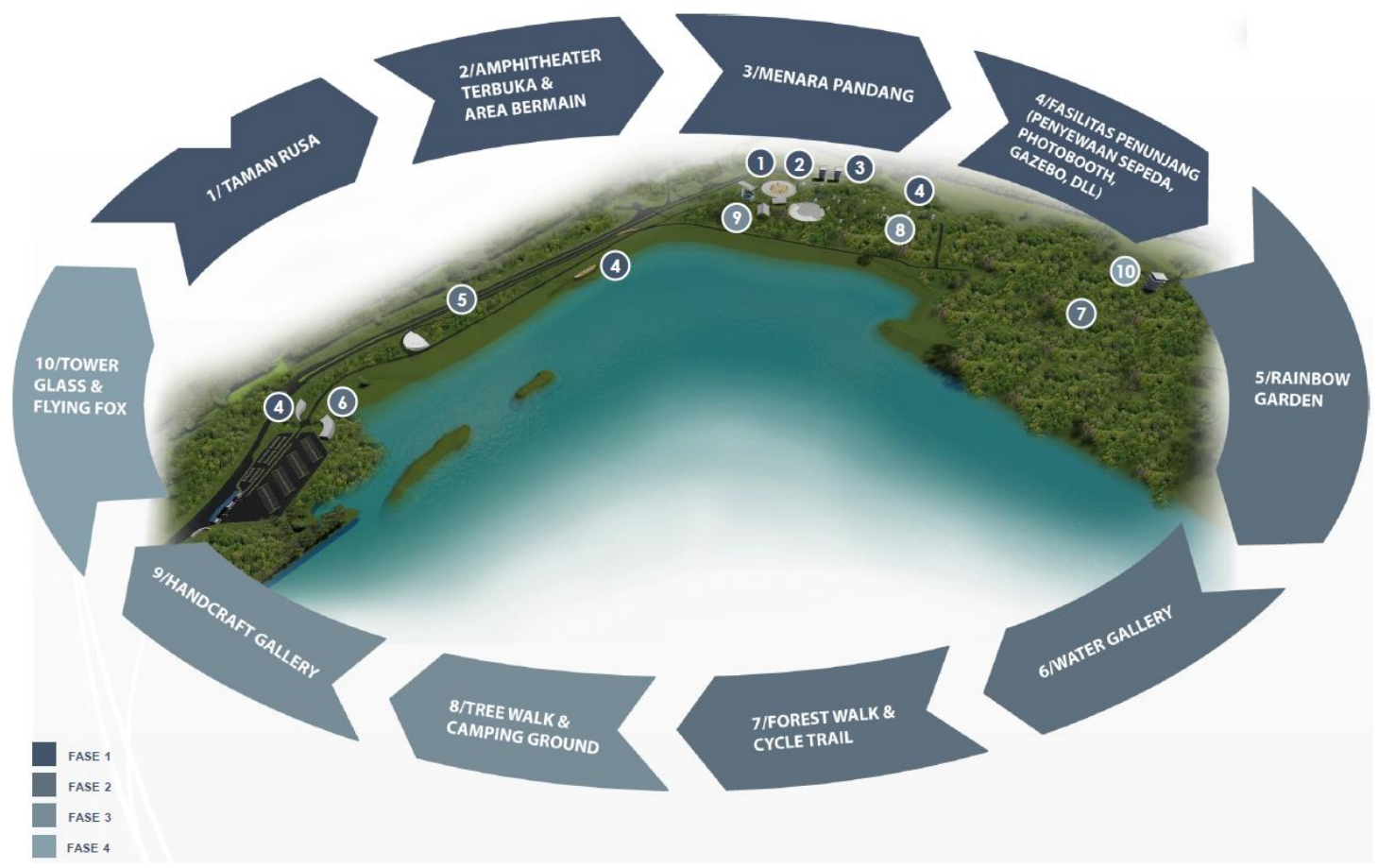

Gambar 4. Gambar Konsep 3D Potensi Pengembangan Ekowisata Berbasis Edukasi di Kawasan Waduk Sei Ladi 
Jurnal Arsitektur ALUR - Vol 4 No 1 Mei 2021

e-ISSN 2685-1490; p-ISSN 2615-1472

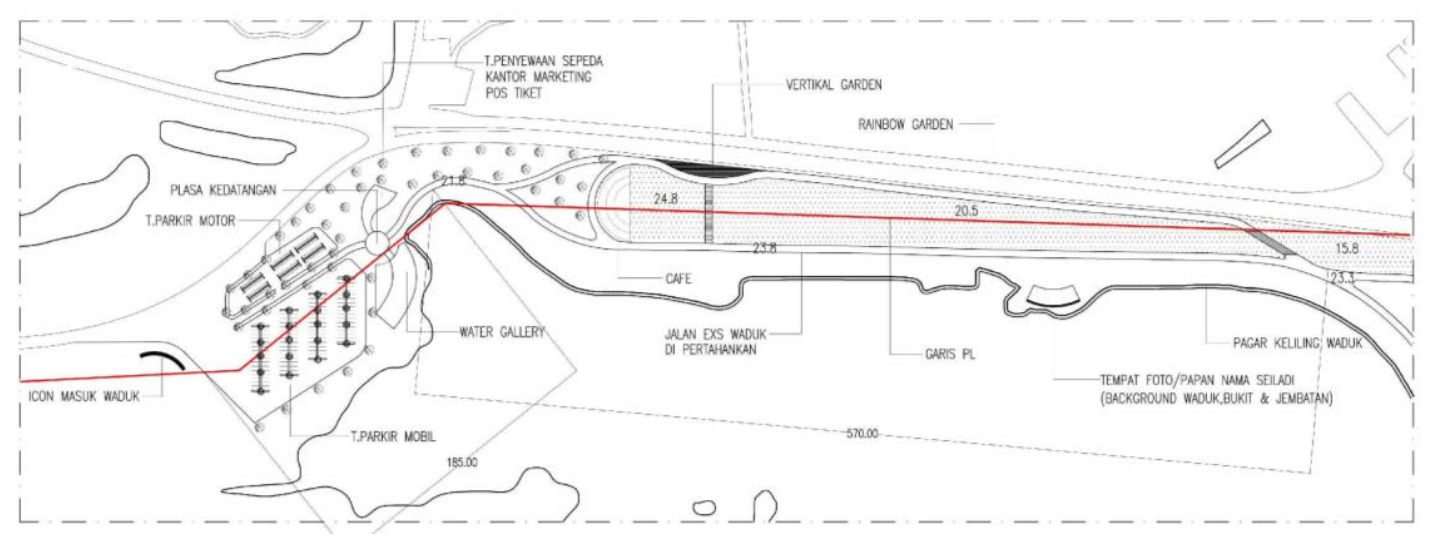

Gambar 5. Siteplan - Zona 1

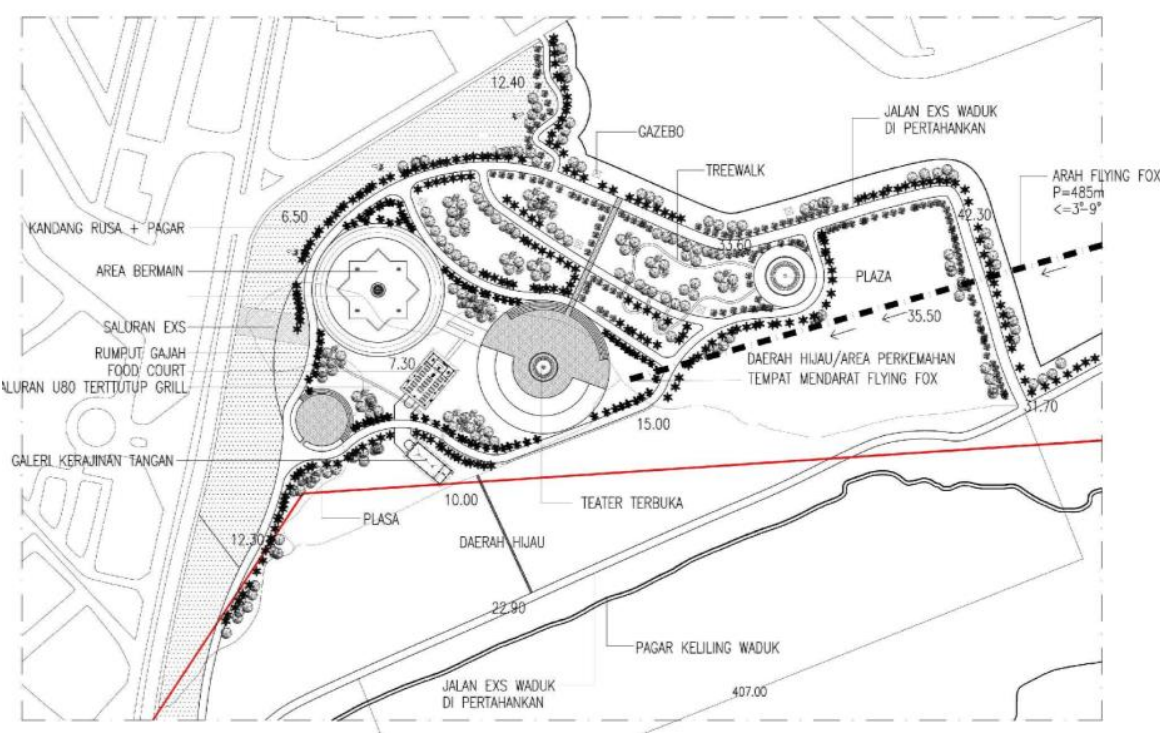

Gambar 6. Siteplan - Zona 2

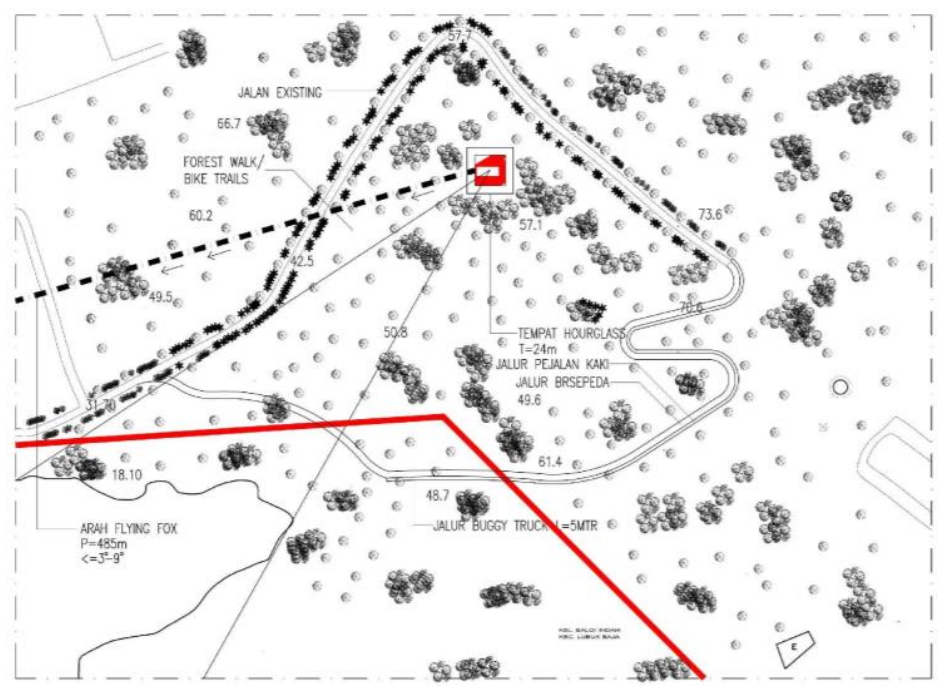




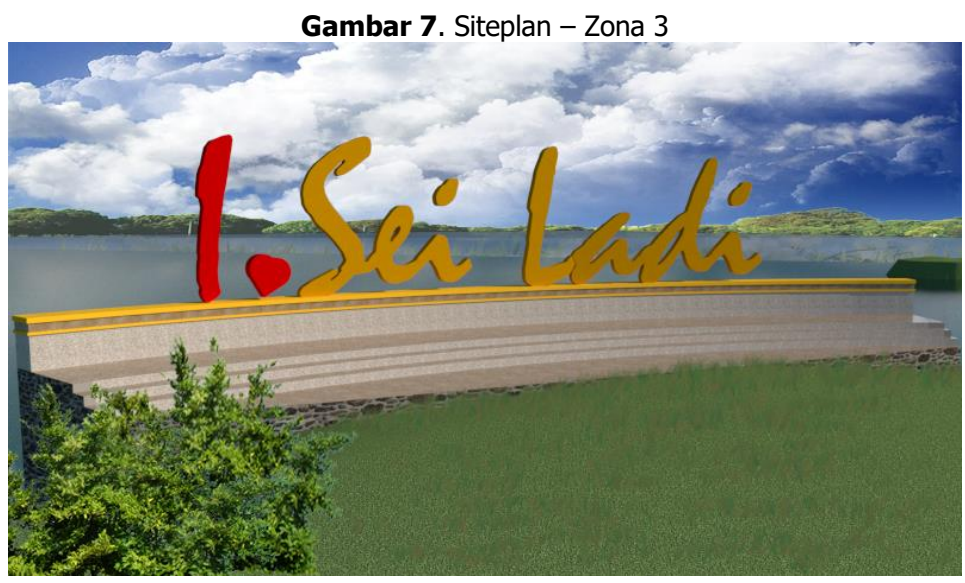

Gambar 8. Ikon Kawasan Sebagai Area Photobooth

\section{Kesimpulan dan Saran}

\section{Kesimpulan}

Berdasarkan hasil analisis dan pembahasan, dapat disimpulkan bahwa kawasan Waduk Sei Ladi di Kota Batam memiliki potensi yang baik untuk dikembangkan sebagai kawasan ekowisata berbasis edukasi dengan tiga zona wilayah melalui empat tahap fase konstruksi. Hal ini didukung dengan adanya daya tarik kawasan yang beragam mulai dari keasrian lingkungan hingga pemandangan yang indah, lalu persepsi masyarakat yang positif terhadap pengembangan di kawasan tersebut, dan kebijakan pemerintah setempat yang mendukung pengembangan kawasan Waduk Sei Ladi sebagai objek wisata berwawasan lingkungan. Implementasi ekowisata berbasis edukasi dapat dimulai dengan melibatkan masyarakat setempat dalam proses perencanaan sampai penyediaan fasilitas yang dapat memberikan edukasi kepada pengunjung.

\section{Saran}

Dengan mempertimbangkan peran Waduk Sei Ladi yang signifikan sebagai sarana penyediaan sumber daya air di beberapa wilayah Kota Batam, maka diperlukan kajian lebih dalam terkait sistem perlindungan terhadap ancaman kegiatan yang dapat merusak ekosistem di wilayah tersebut. Hal ini bertujuan untuk mengoptimalkan pengembangan kawasan ekowisata berbasis edukasi yang berkelanjutan, di mana dapat diwujudkan pula melalui keterlibatan masyarakat setempat dalam hal pengembangan dan pengelolaannya. Selain itu, pendalaman terhadap rencana pengembangan kawasan di wilayah ini juga dapat dilakukan, khususnya yang berkaitan dengan aspek desain yang lebih detail.

\section{Daftar Pustaka}

Arida, I. N. S. (2017). Ekowisata: Pengembangan, Partisipasi Lokal, dan Tantangan. In Cakra Press.

Badan Pusat Statistik Kota Batam. (2020a). Badan Pusat Statistik Kota Batam. https://batamkota.bps.go.id/subject/16/pariwisata.html\#subjekViewTab3

Badan Pusat Statistik Kota Batam. (2020b). Kota Batam dalam Angka 2020: Penyediaan Data untuk Perencanaan Pembangunan (Vol. 66).

Breen, A., Rigby, D., Norris, D. C., (U.S.), W. C., \& Staff, W. C. (1994). Waterfronts: Cities Reclaim Their Edge. McGrawHill.

Fennell, D. (2003). Ecotourism: An Introduction. Routledge.

Peraturan Menteri Dalam Negeri. (2009). Pedoman Pengembangan Ekowisata di Daerah.

Phillips, R., \& Pittman, R. H. (2014). An introduction to community development: Second edition.

Prabudiantoro, B. (1997). Kriteria Citra Waterfront City. Universitas Diponegoro.

Rubenstein, H. M. (1969). A guide to site and environmental planning. New York (N.Y.): Wiley. 